\title{
NATURA, OSOBA, WOLNOŚĆ
}

Pełna analiza etyki, czy też moralności człowieka, jeśli ma być analizą realnie istniejącego konkretu, a nie tylko pewnych możliwości (swoiście rozumianą logiką lub ontologią) nie może się dokonywać poza analizą konkretu ludzkiego, poza antropologią filozoficzną. Bowiem etyka i moralność są czymś ,z człowieka” i „,dla człowieka”, a nie dziedziną swobodnej spekulacji intelektualnej. To znaczy jest to pewna swobodna twórczość, ale jedynie w ramach wyznaczonych poznaniem rzeczywistości, a nie tylko uwarunkowanej tym poznaniem. Poznana rzeczywistość nie jest tylko kanwą, na której człowiek swobodnie tworzy, ale rzeczywistość wyznacza (powinna wyznaczać) moralność człowieka i jej racjonalne uzasadnienia. Niepodobna więc poznać moralności ani też właściwie jej uzasadnić, a tym bardziej wyznaczyć człowiekowi, w jego jednostkowości i w jego wspólnotowości, właściwej roli i właściwego zadania życiowego i ogólno-bytowego bez poznania i pełnego zrozumienia człowieka. Każda więc etyka, czy to filozoficzna, czy też zorientowana na wykorzystanie dorobku nauk szczegółowych, jest albo oparta na pewnym zrozumieniu człowieka albo jest po prostu sama analizą i ujawnianiem człowieka. Świadome i zamierzone badanie struktury człowieka, świadoma filozofia człowieka przyjęta jako warunek lub część integralna etyki pozwala na możliwie pełne wyjaśnienie zjawiska moralności. I tak właśnie należy rozumieć studium Osoba i czyn Kardynała Karola Wojtyły, zgodnie zresztą z intencją samego Autora. Jest to studium osoby ludzkiej w aspekcie właściwego jej działania (czynu), a więc w tym aspekcie, w którym najbardziej i najpełniej ujawnia się osobowość, „ludzkość” człowieka. Jest to więc niejako studium wstępne dla zbudowania pełnej etyki. Jednakże książka ta ma także i inne znaczenie, poza ,byciem dla etyki”. Jest to jedna z najpełniejszych prac właśnie w dziedzinie antropologii filozoficznej jakie ukazały się w polskiej lite- 
raturze filozoficznej. Szczęśliwym trafem ukazała się ona prawie równocześnie z inną, równie ważką, jaką jest Ksiażeczka o człowieku Romana Ingardena.

W tradycyjnych podręcznikach etyki, które nawiązywały do filozofii arystotelesowsko-tomistycznej, znajdują się zawsze rozdziały poświęcone świadomości i wolności działania, oraz przeważnie rozparcelowane w wielu miejscach problemy emocjonalności i cielesności człowieka, innymi słowy wszystko to, co $\mathrm{w}$ jakiś sposób wiąże się z pojęciem natury ludzkiej. I te wszystkie problemy znajdują się też w Osobie i czynie, choć potraktowane są nie tylko jako wstęp do etyki, ale jako problem ważny sam w sobie.

W tych krótkich uwagach chciałbym zatrzymać się na analizach wolności człowieka, przeprowadzonych w wymienionej książce. Autor od pewnego czasu stara się, jak można się domyśleć choćby z treści wielu publikacji, dokonać syntezy tradycyjnej filozofii arystotelesowsko-tomistycznej ze współczesną fenomenologią. Wydaje się, że właśnie na terenie zagadnienia wolności człowieka proces tej syntezy został najdalej i w najlepszy sposób dokonany. Przejawia się to w połączeniu tradycyjnego „obiektywizmu” z fenomenologicznym ,subiektywizmem”. Dzięki temu połączeniu przedstawiony obraz wolności człowieka jest chyba najpełniejszy we współczesnej literaturze polskiej. Połączenie analizy sfery przeżyciowej $\mathrm{z}$ analizą struktury ontycznej człowieka, a więc analiza wolności prowadzona na dwóch płaszczyznach wzajemnie się uzupełniających wskazuje, że droga ta jest płodna i dająca rezultaty. Nie chodzi tutaj o sam pomysł połączenia tych dwóch koncepcji filozoficznych, ale przede wszystkim o wykonanie go. Prób takiej syntezy było już dosyć dużo, ale niewiele, jak dotąd, było udanych. Robiono je głównie na dwa sposoby: wychodząc od koncepcji tomistycznych (,obiektywnych") lub fenomenologicznych (albo egzystencjalistycznych, „subiektywnych”). Główną przyczyną nieudawania się ich było to, że były one sztuczne, że tworzono nie jakąś strukturalną całość, ale dziwne hybrydy, nieuzasadnione ekstrapolacje, lub dokonywane zmiany były tylko w sferze językowej. Na przykład brana wyniki jednego i drugiego typu filozofii i łączono je przy pomocy niezbyt skomplikowanych zabiegów w jedną, ale nieorganiczną całość, względnie traktowano osiągnięcia jednej filozofii jako uzasadnienie drugiej nie bacząc na zasadnicze różnice między nimi, na to, że tylko pozornie (językowo) mówią o tym samym. Najbardziej zaś nieudanymi próbami było prawie mechaniczne zastępowanie terminów jednej filozofii terminami drugiej. Przy pomocy takiego zabiegu chciano osiągnąć „zobiektywizowanie” lub ,unowocześnienie" filozofii. Zabieg ten był na tyle żałosny co nieodpowiedzialny. Na całe szczęście nie brak i prób udanych (jeśli nie w całości, to przynajmniej częściowo), 
wynikających nie tylko ze znajomości obu rodzajów filozofii, ale przede wszystkim z tego, że stanowią one tkankę żywego filozofowania. Tylko taka próba może być udana, która jest dobrą filozofią.

Rozpoczęcie analizy wolności od uwarunkowań świadomościowo-poznawczych pozwala na uchwycenie tej zasadniczej prawdy, że dynamizm ludzki, którego cechą istotną jest wolność, nie jest po prostu energią, ale energią ukierunkowaną przez podmiot, przez jego świadomość i poznanie. Co więcej, wolność jest właśnie energią świadomego, poznającego i wiedzącego podmiotu. Bez tych elementów, bez jakiejś istotnej, wewnątrzpodmiotowej ich jedności nie można mówić o wolności ludzkiej.

Najogólniej rzecz biorąc analiza wolności, jak zresztą cała analiza antropologiczna, w obu porządkach filozoficznych różni się pewną podstawową bazą, podstawowym punktem odniesienia — w Osobie $i$ czynie doszło właśnie do ich konfrontacji. W tomizmie taką bazą (pojęciem bazowym) jest pojęcie osoby rozumianej jako substancja, jako konkretna natura rozumna człowieka, natomiast w fenomenologii (i chyba także w egzystencjalizmie) takim pojęciem jest osoba jako pewne centrum, lub, w zależności od spojrzenia, najwyższa albo najgłębsza warstwa człowieka. Pojęcie natury konstytuowanej przez jedną formę substancjalną człowieka (ostatecznie przez odpowiednie jej istnienie) powoduje, że człowiek niejako a priori stanowi organiczną i substancjalną jedność, nawet przy wielości władz. Równocześnie realna różnica między różnymi dynamizmami, z których każdy posiada właściwą sobie strukturę oraz sposób przejawiania się, powoduje, że mimo wszystko dynamizmy te zostają niejako ,rozparcelowane” uzyskując jakby samoistność (quasi-substancjalność), gdyż pojęcie natury ludzkiej, obejmujące zasadniczo całego człowieka, wydaje się zbyt ogólne i nad-złożone. Jedność substancjalna podmiotu jest oczywista, natomiast pewną tajemnicą wydaje się być różnorodność przejawiania się tej jedności. Ta jedność w wielości (czy też na odwrót) powoduje duże trudności w wyjaśnieniu, w jaki sposób w aktach różnych wladz przejawia się ta sama natura człowieka. Z drugiej zaś strony pozwala to na lepsze poznanie specyfiki poszczególnych władz (dynamizmów) człowieka, oraz na łatwiejsze uchwycenie faktu, iż w każdym dynamizmie, w każdym akcie przejawia się cała natura człowieka. Dzięki temu samoposiadanie, samopanowanie i samostanowienie, te podstawowe elementy (albo ,piętra”) wolności ludzkiej są zrozumiała i naturalną konsekwencją takiej wizji człowieka. Ponadto osoba rozumiana jako pełna natura, a nie jeden jej element (nawet najgłębszy czy centralny) pozwala w sposób naturainy objąć swoim wolnym samostanowieniem całość przejawów natury (proporcjonalnie oczywiście do swoistości różnych przejawów, a nie w każdym jednakowo), a nie tylko przejaw owego centrum (jednej warstwy człowieka). 
Przyjęcie pojęcia osoby jako centrum człowieka za punkt odniesienia analizy antropologicznej pozwala na łatwiejsze zobaczenie jak różne władze (ale czy wszystkie?) łączą się ze sobą, w jaki sposób przejawia się $w$ nich ten sam podmiot, gdyż jest on w tym wypadku mniej złożony. $\mathrm{Z}$ drugiej zaś strony rozumienie pojęcia osoby jako tego, co jest najbardziej ludzkie w człowieku powoduje, że zanika do pewnego stopnia różnorodność elementów w przejawach dynamizmów człowieka tylko część elementów jest ludzka, albo w pełni ludzka. Ten sposób widzenia dotyczy także samej struktury - pewne elementy strukturalne są „,bardziej”, inne „mniej” ludzkie, a jedność substancjalna człowieka zostaje zachwiana przez jawne lub ukryte przyjęcie wielości form substancjalnych w człowieku. W ten sposób zostaje mimo pozorów jeszcze bardziej zaciemniony obraz człowieka i jeszcze trudniej zrozumieć dlaczego człowiek może działać w różnorodny sposób. Między doświadczeniem przejawów człowieka a doświadczeniem strukturalnej jedności powstaje rozziew.

Pogodzenie tradycyjnej koncepcji natury ludzkiej z tak specyficznym pojęciem osoby jest szczególnie trudne już choćby $z$ tego powodu, że pojęcia te są $w$ różny sposób rozumiane i chyba nie istnieją na jednej płaszczyźnie. Powoduje to wielkie kłopoty i kontrowersje - wystarczy tu wspomnieć na dyskusje dotyczące rozumienia natury i osoby, toczące się przy okazji ogłoszenia encykliki Humanae vitae. Jest to tym bardziej kłopotliwe, że pojęcie natury stanowi podstawę pojęcia prawa naturalnego (to jest moralnego).

Złożoność natury oraz niejasność i nieostrość tego pojęcia występująca często $\mathrm{w}$ opracowaniach tomistycznych powoduje, że na terenie tej filozofii o wiele chętniej stosuje się formalne, niż treściowe pojęcie natury, to znaczy raczej określa się c zym on a jest w człowieku, jakie ma znaczenie itp., niż co to jest natura, jaką ma dokładnie treść (szczególnie określając prawo naturalne) — zresztą mimo prostszego pojęcia osoby $w$ fenomenologii sytuacja jest podobna, a do tego dochodzi jeszcze duża różnica między różnymi przedstawicielami tej szkoły. Dzięki temu znajduje się $\mathrm{W}$ obiegu wiele terminów bliskoznacznych, jak na przykład ogólniejsze pojęcie natury ludzkiej, bardziej szczegółowo czy cząstkowo określające pojęcia natury rozumnej, wolnej, biologicznej itp., oraz pojęcie natury utożsamiające się z tym, co przyrodnicze, będące przeciwstawieniem $\mathrm{w}$ większym lub mniejszym stopniu tamtych pojęć. W zależności od potrzeb używa się jednego z tych pojęć. Tak się rzecz ma i $\mathrm{w}$ Osobie $i$ czynie. Autor posługuje się raz pojęciem natury $=$ przyrody (np. ,Na poziomie dynamizmu samej natury nie ma działania, nie ma czynów, są tylko — ściśle biorąc «uczynnienia»" — s. $120 ;, \ldots$ dy-namizmowi na poziomie natury przeciwstawia się dynamizm na poziomie 
osoby..." - s. 121; „... dynamizmowi na poziomie samej natury, dynamizmowi, którego czynnikiem integrującym jest instynkt, przypisuje się konieczność jako przeciwieństwo wolności, która właściwa jest osobie..." s. 122), raz pojęciem natury równoznacznym ze stałością bytu, z jego substancjalnością (s. 191), a raz pojęciem natury = struktury istotnej lub właściwej danemu bytowi (,,.. »natura rozumna bytuje realnie tylko i wyłącznie jako osoba” — s. 127; „człowieczeństwo czyli natura ludzka” — s. 192; „,... do natury ludzkiej koniecznie przynależy wolność woli" — s. 192). Pełne zrozumienie natury jest utrudnione przez dość płynne określenia treści tych pojęć, ich zakresu i wzajemnych związków. Obok pojęcia (pojęć) natury Autor posługuje się innymi pojęciami, niejako konkurencyjnymi, które w pewnych kontekstach mają precyzować to, co znaczy natura, a mianowicie pojęciem ,,ja”, osoba, człowiek, oraz ich kombinacjami, jak np. natura osoby. I tutaj istnieje pewien kłopot. Jeśli nie ma dokładnie wyznaczonej treści i relacji między tymi pojęcami oraz między nimi a pojęciami natury, to nie można zorientować się w jakim znaczeniu i zakresie doszło do syntezy. Tym bardziej jest to niewiadome, że nie zostało pokazane w jaki sposób analizy fenomenologiczne stanowią uzasadnienie dla wskazania struktury ontycznej człowieka. Czy opis fenomenologiczny znajduje się na tej samej płaszczyźnie co analiza metafizyczna w tradycyjnym rozumieniu?

Stąd istniejące niedookreślenia, a mianowicie: czego dotyczy we właściwym sensie wolność - czy tylko osoby, czy też natury, czy „ja”, czy też pewnego ich wzajemnego ułożenia. Co więcej, czy można mówić o wolności osoby, skoro jest ona właściwie czymś asubstancjalnym (,,Osoba jest tylko w części i pod pewnym względem mianowicie pod wzgledem substancjalności sprowadzalna do natury. W całości - i co do swej najgłębszej istoty - pozostaje do niej niesprowadzalna" - s. 191-192). Osoba jest pewną dynamiczną strukturą, czy organizacją cech $(,, \ldots$ osoba czyli zupełnie swoista struktura samo-posiadania i samo-panowania" s. 188), jest pewną wewnętrzną relacją człowieka do samego siebie, i w tym pojęcie to jest zbliżone do pojęcia osobowości we współczesnej psychologii (choć jest ono tak bardzo różnorodne). Ale czy wobec tego nie należy mówić raczej o wolności jako czymś charakterystycznym dla natury ludzkiej właśnie? Jeśli więc osoba jest zapodmiotowana w naturze, jest czymś na naturze nabudowanym, a natura jest substancjalnym podłożem osoby, to czy nie należałoby mówić w tym wypadku o wolności i czynie (akcie) natury, które przejawiają się w i poprzez osobę?

Myślę, że wydobycie całej treści tych pojęć oraz ukazanie ich wzajemnego stosunku uwypukliłoby bardzo precyzyjne opisy wolności człowieka, opisy, których dokładność i pełność mało mają sobie równych w polskiej literaturze filozoficznej. Jest to właśnie wynik syntezy tych 
dwóch wyżej wspomnianych kierunków filozoficznych - pogłębionych analiz wewnętrznych przy jednoczesnym odnoszeniu ich wyników do struktury ontycznej człowieka. Być może, iż pewne dookreślenia dotyczące właśnie struktury bytowej (dotyczące pojęć: natura, osoba, ,ja”, człowiek, itd.) doprowadziłoby zarówno do mocniejszego związania pojęcia wolności ze strukturą ontyczną człowieka, jak i do pewnych korektur w określeniu natury ludzkiej. 